\title{
Preliminary account of Late Devonian palynomorph assemblages from the Bedford Shale and Berea Sandstone Formations of central Ohio, U.S.A.
}

\author{
STEWART G. MOLYNEUX ${ }^{1}$, WALTER L. MANGER ${ }^{2}$ \& BERNARD OWENS \\ ${ }^{1}$ British Geological Survey, Keyworth, Nottingham, England. \\ ${ }^{2}$ Dept. of Geology, University of Arkansas, Fayetteville, Arkansas 72701, U.S.A.
}

\begin{abstract}
Diverse assemblages of well preserved miospores and microplankton have been obtained from a series of samples collected across the boundary between the Bedford Shale and Berea Sandstone Formations in central Ohio. The miospores indicate a Late Devonian (pre-Carboniferous Tournaisian)* age for each of the samples. The microplankton support this age determination. A number of microplankton species not previously recorded from North America are present.
\end{abstract}

\section{INTRODUCTION}

Four samples collected across the boundary between the Bedford Shale and Berea Sandstone Formations in central Ohio have yielded well preserved assemblages of both miospores and microplankton. The boundary between these formations has been placed by various authors in either the Upper Devonian or the Mississippian.

De Witt (1970) concluded, on the basis of conodont evidence reported by Haas (1947), that only the basal few feet of the Bedford Shale Formation was of Late Devonian age with the remainder of the Bedford Shale and the entire Berea Sandstone Formation being Early Mississippian (Carboniferous) in age. This conclusion was based on the occurrence in the basal Bedford Shale, of Spathognathodus anteposecornis Scott, a species that is characteristic of the latest Devonian Protognathodus fauna in the Upper Mississippi Valley. Conodonts have not been reported from the upper part of the Bedford Shale or Berea Sandstone Formations.

Eames (1978), in contrast, has reported an Upper Devonian age, based on palynological evidence, for the entire Bedford Shale and Berea Sandstone in northern Ohio. Previous palynological work in Ohio by Winslow (1962) and in southern Ontario by McGregor (1967, 1970 and 1979) on the Bedford Shale and Berea Sandstone Formations and their lateral equivalents would tend to support this conclusion when direct comparisons are drawn with the well established biostratigraphies in the Ardenno-Rhineland areas of Belgium and West Germany. The samples from Big Walnut Creek, Sunbury, discussed in the present account clearly indicate a Late Devonian (Tn 1a - lower Tn 1b) age. Additional sampling in the Berea Sandstone would be necessary before any attempt could be made to define precisely the Devonian-Carboniferous (Mississippian) boundary.

\section{LITHOSTRATIGRAPHY}

The Bedford Shale and Berea Sandstone Formations have been interpreted as the deposits of an elongate delta system prograding southward across the Ohio Black Shale of the Appalachian Basin during the Late Devonian and Early Carboniferous (Pepper et al., 1954). At its type locality in northeastern Ohio, the Bedford Shale Formation consists of $85 \mathrm{ft}$. of grey and bluish-grey shale with grey, irregularly bedded siltstones at its base. Elsewhere in north-central Ohio, red colouration predominates in the Bedford Shale, but this feature decreases in intensity eastward into Pennsylvania and southward into Kentucky. The sandstone and siltstone contents increase in the same direction. The contact with the underlying Ohio Black Shale is regarded as gradational and conformable throughout most of Ohio, with black shale stringers occurring in the basal part of the Bedford Shale (Pepper et al., 1954, p. 159; Hoover, 1960 , p. 27).

The Berea Sandstone consists primarily of fine to medium-grained, pale-coloured, quartz sandstone, very variable in thickness. Generally the lower part of the Berea Sandstone is a massive cross-bedded sandstone interpreted as the infill of channels eroded into the Bedford Shale and in some cases older formations. The upper part of the Berea Sandstone is dominated by thinbedded, oscillation-ripple bedforms thought to represent a transgressive phase of the Bedford-Berea deposition (Pepper et al., 1954).

*The definition of the Devonian-Carboniferous boundary proposed by Conil, Groessens \& Pirlet (1977) at the top of the costatus conodont zone within Tn1b, in Belgium is utilised here. This implies the lowest part of the Tournaisian Series, as previously defined, is now regarded as uppermost Devonian. 
The Bedford Shale - Berea Sandstone contact is sharp and markedly erosional in northern Ohio, but becomes conformable and gradational to the south, with similar lithological sequences developed in the upper part of the Bedford Shale and the lower part of the Berea Sandstone. In southern Ohio and northern Kentucky, the two formations are thin and cannot be differentiated. At the Sunbury exposure (see Fig. 1) the contact does not appear to be erosional although channelling has been reported in the area (Pepper et al., 1954). The formation boundary is there taken at the upward change from flaggy weathering shaly siltstones and thin sandstones to more massive sandstones with flow rolls.

\section{SAMPLE DETAILS}

The Bedford Shale-Berea Sandstone boundary is well exposed in a bluff on the west side of Big Walnut Creek immediately downstream from the Croton Road bridge at Sunbury, Ohio (SE $\frac{1}{4}, \mathrm{SE} \frac{1}{4}$, sec. 1, T4N, R17W, Sunbury, 1973, $7 \frac{1}{2}$ quadrangle, Delaware County). Four samples were collected as indicated in Fig. 1.

1. Thin shale within Berea Sandstone immediately below massive sandstone with flow rolls.

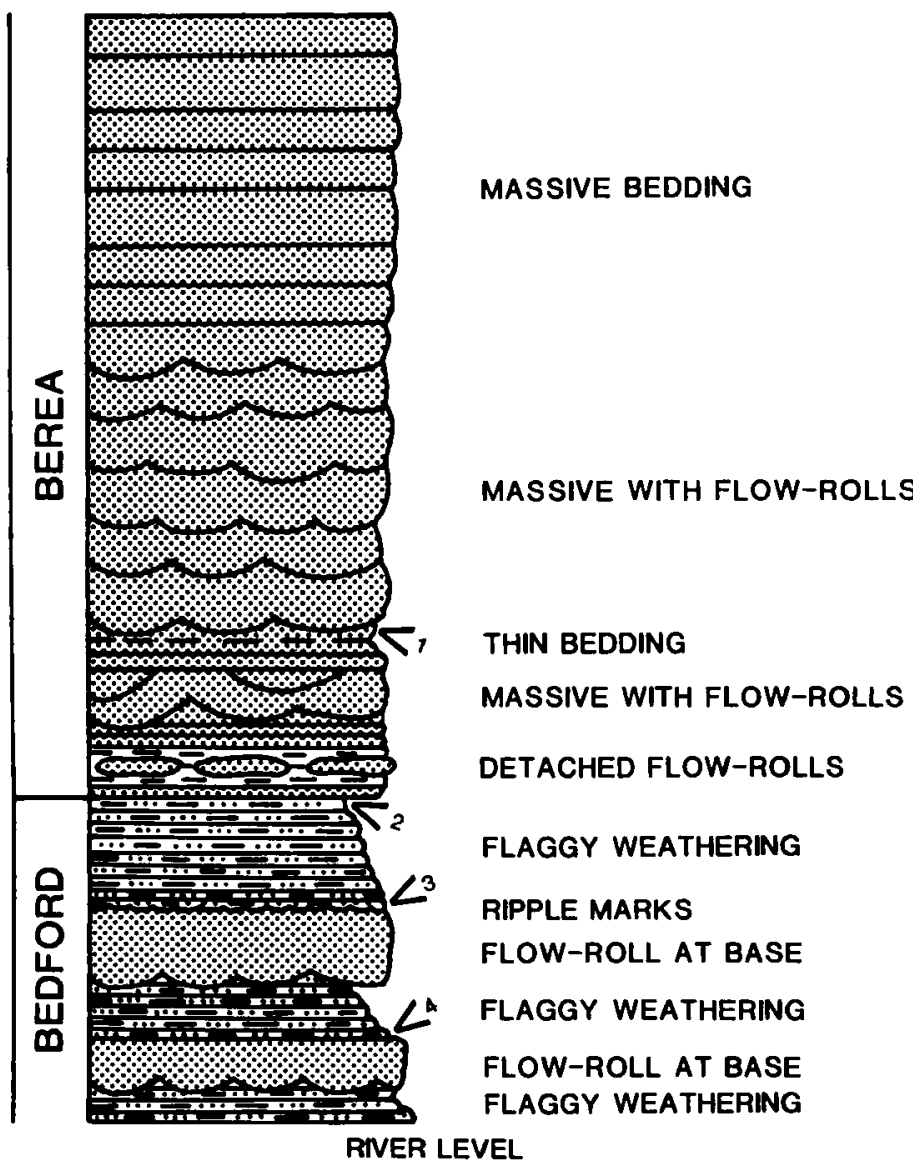

2. Shale at top of Bedford Shale, immediately below the contact.

3. Silty shale, $3 \mathrm{ft}$. below the top of the Bedford Shale, resting on a ripple marked surface.

4. Silty shale $6 \mathrm{ft} .4 \mathrm{in}$. below the top of the Bedford Shale.

Figured material is housed in the Palynological Collections of the British Geological Survey, Keyworth, Nottingham, England, and registered in the series MPK 4007-4030. Representative assemblage slides from all four samples will be deposited in the collections of the British Geological Survey, Keyworth and the Department of Geology, University of Arkansas, Fayetteville, Arkansas, U.S.A.

\section{STRATIGRAPHIC PALYNOLOGY}

\section{a) Miospores}

The composition of the miospore assemblages from the four samples studied are represented diagrammatically in Table 1. All the assemblages are well preserved, but

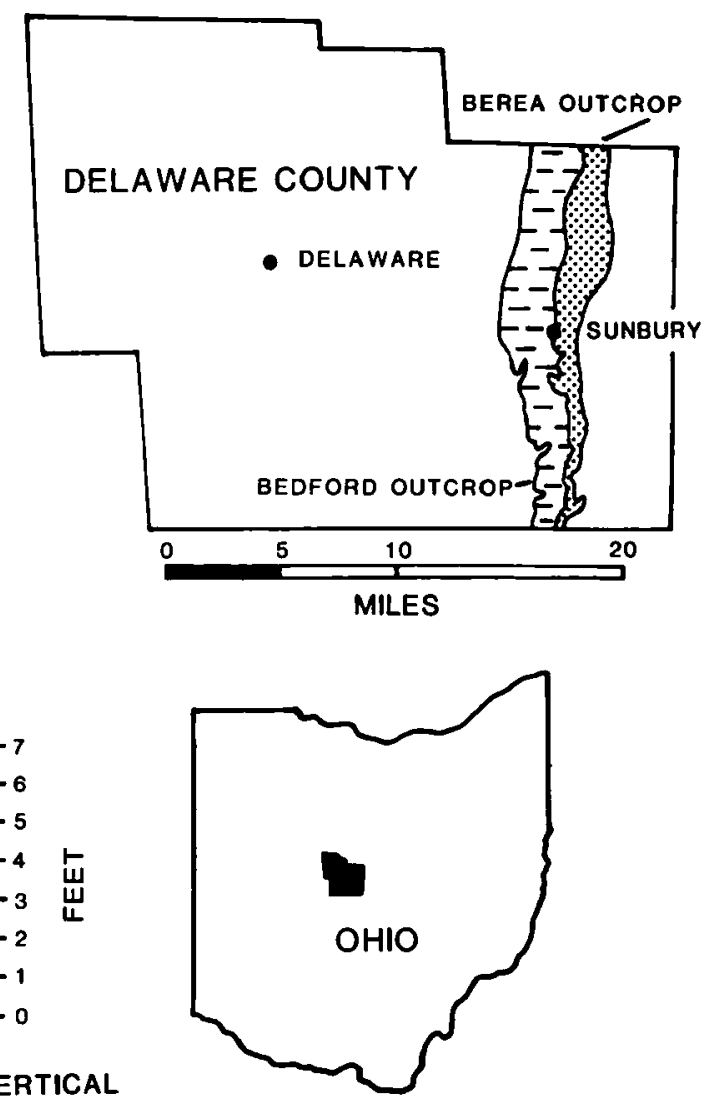

Fig. 1. Stratigraphic distribution of samples from the Bedford Shale and Berea Sandstone Formations, Big Walnut Creek, Sunbury, Ohio. 
Table 1. Stratigraphic distribution of miospores

MIOSPORE TAXA

\begin{tabular}{|c|c|c|c|}
\hline \multicolumn{3}{|c|}{ Bedford } & \multirow{2}{*}{$\frac{\text { Berea }}{1}$} \\
\hline 4 & 3 & 2 & \\
\hline $\mathrm{x}$ & & $\mathbf{x}$ & $\mathbf{x}$ \\
\hline \multicolumn{4}{|l|}{$\mathrm{x}$} \\
\hline $\mathbf{x}$ & $\mathbf{x}$ & & \\
\hline $\mathbf{x}$ & $\mathbf{x}$ & $\mathbf{x}$ & $\mathbf{x}$ \\
\hline $\mathbf{x}$ & $\mathbf{x}$ & & \\
\hline \multirow[t]{2}{*}{$\mathbf{x}$} & & $\mathbf{x}$ & $\mathrm{x}$ \\
\hline & & $\mathbf{x}$ & \\
\hline \multicolumn{4}{|l|}{$x$} \\
\hline $\mathbf{x}$ & & & $\mathbf{x}$ \\
\hline$x$ & & $\mathbf{x}$ & $\mathbf{x}$ \\
\hline \multicolumn{4}{|l|}{$\mathbf{x}$} \\
\hline $\mathbf{x}$ & & & $x$ \\
\hline \multicolumn{4}{|l|}{$\mathbf{x}$} \\
\hline \multicolumn{4}{|l|}{$\mathrm{x}$} \\
\hline \multicolumn{4}{|l|}{$\mathbf{x}$} \\
\hline \multicolumn{4}{|l|}{$\mathbf{x}$} \\
\hline \multicolumn{4}{|l|}{$\mathbf{x}$} \\
\hline $\mathrm{x}$ & & & $\mathbf{x}$ \\
\hline \multicolumn{4}{|l|}{$\mathbf{x}$} \\
\hline \multicolumn{4}{|l|}{$\mathrm{x}$} \\
\hline $\mathbf{x}$ & $\mathbf{x}$ & $\mathbf{x}$ & \\
\hline \multirow[t]{3}{*}{$\mathrm{x}$} & $\mathbf{x}$ & & \\
\hline & & $\mathbf{x}$ & \\
\hline & & $\mathrm{x}$ & \\
\hline $\mathbf{x}$ & $\mathbf{x}$ & $\mathbf{x}$ & $\mathbf{x}$ \\
\hline $\mathbf{x}$ & & & $\mathbf{x}$ \\
\hline \multicolumn{4}{|l|}{$\mathrm{x}$} \\
\hline $\mathbf{x}$ & $\mathbf{x}$ & $\mathbf{x}$ & \\
\hline \multicolumn{4}{|l|}{$\mathbf{x}$} \\
\hline \multicolumn{4}{|l|}{$x$} \\
\hline & & $\mathrm{x}$ & \\
\hline $\mathbf{x}$ & & $\mathrm{x}$ & \\
\hline
\end{tabular}

Calamospora microrugosa (Ibrahim) Schopf, Wilson \& Bentall

Punctatisporites irrasus Hacquebard

$P$. solidus Hacquebard

Retusotriletes incohatus Sullivan

Apiculiretusispora multiseta (Luber) Butterworth \& Spinner

Verrucosisporites nitidus (Naumova) Playford

Acanthotriletes persibius Higgs

Emphanisporites rotatus (McGregor)

Hystricosporites multifurcatus (Winslow) Mortimer \& Chaloner

$H$. porcatus (Winslow) Allen

Convolutispora tuberosa Winslow

Dictyotriletes [Reticulatisporites] fimbriatus (Winslow)

D. submarginatus Playford

D. trivialis Naumova

Corbulispora cancellata (Waltz) Bharadwaj \& Venkatachala

Crassispora catenata Higgs

Reticulatisporites sp. cf. Canthospora patula Winslow

Lophozonotriletes cristifer (Luber) Kedo

Knoxisporites [Reticulatisporites] crassus (Winslow)

$K$. literatus (Waltz) Playford

$K$. pristinus Sullivan

Vallatisporites pusillites (Kedo) Dolby \& Neves

$V$. verrucosus Hacquebard

Hymenozonotriletes submirabilis (Luber) Kedo

H. explanatus (Luber) Kedo

Spelaeotriletes lepidophytus (Kedo) Streel

$S$. resolutus Higgs

Auroraspora hyalina (Naumova) Streel

Rugospora flexuosa (Juschko) Streel

Grandispora cornuta Higgs

G. echinata Hacquebard

Calyptosporites cf. triangulatus Higgs

Discernisporites micromanifestus (Hacquebard) Sabry \& Neves

Perotrilites perinatus Hughes \& Playford

that from sample $4(6 \mathrm{ft}$. 4 ins. below the top of the Bedford Shale) is the most diverse. The commonest components of all four assemblages are representatives of the species Spelaeotriletes lepidophytus. The Bedford Shale assemblages (samples 2, 3 and 4) are characterised by the following miospore association: Retusotriletes incohatus, Apiculiretusispora multiseta, Hystricosporites multifurcatus, Convolutispora tuberosa, Dictyotriletes [Reticulatisporites] fimbriatus, D. trivialis, Crassispora catenata, Reticulatisporites sp. cf. Canthospora patula, Lophozonotriletes cristifer, Vallatisporites pusillites, $V$. verrucosus, Spelaeotriletes lepidophytus, S. resolutus, Auroraspora hyalina, Rugospora flexuosa and Grandi- spora echinata. In the uppermost Bedford shale sample (sample 2, adjacent to the contact with the Berea Sandstone) the assemblages are supplemented by the appearance of Acanthotriletes persibius, Hymenozonotriletes explanatus, $H$. submirabilis and Calyptosporites cf. triangulatus.

The single sample from the base of the Berea Sandstone (sample 1) yielded a miospore population which is closely comparable to those from the underlying Bedford Shale. Representatives of Spelaeotriletes lepidophytus are again quantitatively significant components of the assemblage. Two species, Corbulispora cancellata and Hystricosporites (Dicrospora) porrectus, make their first 
appearance in this sample and Emphanisporites sp., Hymenozonotriletes explanatus, Vallatisporites pusillites, Rugospora flexuosa and Calyptosporites triangulatus, present in the Bedford Shale, are absent here. The difference between the assemblages from these two formations may reflect stratigraphical distribution of the components, but may equally be the result of environmental controls.

\section{Comparison with other North American assemblages}

The most extensive previous study of late Devonian early Mississippian palynomorph assemblages in the north-central United States is that of Winslow (1962) based on material from surface and borehole sections in central and northeast Ohio. One of Winslow's sections (Locality 9) was in Franklin County, adjacent to Sunbury, where a comparable Bedford Shale and Berea Sandstone interval was examined together with part of the overlying Sunbury Shale. The results obtained from this section compare closely with those of the present study. Spelaeotriles lepidophytus (recorded as Endosporites lacunosus) with Dictyotriletes fimbriatus (Reticulatisporites fimbriatus), Vallatisporites pusillites (Cirratriradites hystricosus and Lycospora sp. A), Reticulatisporites sp. cf. Canthospora patula, Knoxisporites [Reticulatisporites] crassus and Emphanisporites rotatus (Radforthia radiata) were reported in both the Bedford Shale and Berea Sandstone. Only one species, Hystricosporites multifurcatus, which in the present study was recorded in the Bedford Shale and basal Berea Sandstone, was found to have a different range, being restricted to the Bedford Shale in Winslow's account. The presence of Vallatisporites pusillites in Winslow's Berea Sandstone assemblages supports the view that its absence from that formation in the Sunbury area is more probably the result of ecological controls than the result of its stratigraphical distribution.

McGregor (1970) has reviewed the distribution of Spelaeotriletes lepidophytus from the Late Devonian rocks of Canada. He reported that Spelaeotriletes

\section{Explanation of Plate 1}

Fig. 1. Emphanisporites rotatus (McGregor) McGregor, 1973. Specimen MPK 4007. Sample 1. England Finder coordinates N26/3 $(\times 500)$.

Fig. 2. Spelaeotriletes lepidophytus (Kedo) Streel, 1974. Specimen MPK 4008. Sample 2. England Finder coordinates M33/4 $(\times 500)$.

Fig. 3. Spelaeotriletes lepidophytus (Kedo) Streel, 1974. Specimen MPK 4009. Sample 2. England Finder coordinates $\mathrm{N} 26 / 0(\times 500)$.

Fig. 4. Emphanisporites rotatus (McGregor) McGregor, 1973. Specimen MPK 4010. Sample 1. England Finder coordinates M41/0 $(\times 500)$.

Fig. 5. Knoxisporites [Reticulatisporites] crassus (Winslow, 1962). Specimen MPK 4011. Sample 4. England Finder co-ordinates M31/0 ( $\times 500)$.

Fig. 6. Dictyotriletes [Reticulatisporites] fimbriatus (Winslow, 1962). Specimen MPK 4012. Sample 3. England Finder co-ordinates 016/3 $(\times 500)$.

Fig. 7. Hymenozonotriletes explanatus (Luber) Kedo, 1963. Specimen MPK 4013. Sample 3. England Finder coordinates 029/2 ( $\times 500)$.

Fig. 8. Hystricosporites porcatus (Winslow) Allen, 1965. Specimen MPK 4014. Sample 3. England Finder coordinates Q39/0 $(\times 500)$.

Fig. 9. Hystricosporites multifurcatus (Winslow) Mortimer \& Chaloner, 1967. Specimen MPK 4015. Sample 3. England Finder co-ordinates N24/0 $(\times 500)$.

Fig. 10. Unellium elongatum Wicander, 1974. Specimen MPK 4016. Sample 2. England Finder co-ordinates N38/2 $(\times 490)$.

Fig. 11. Stellinium comptum Wicander \& Loeblich, 1977. Specimen MPK 4017. Sample 4. England Finder coordinates 043/1 $(\times 780)$.

Fig. 12. Umbellasphaeridium saharicum Jardine, Combaz, Magloire, Peniguel \& Vachey, 1972. Specimen MPK 4018. Sample 4. England Finder co-ordinates 042/1 ( $\times 490)$.

Fig. 13 Exochoderma irregulare Wicander, 1974. Specimen MPK 4019. Sample 4. England Finder co-ordinates S52/1 ( $\times 580)$. 

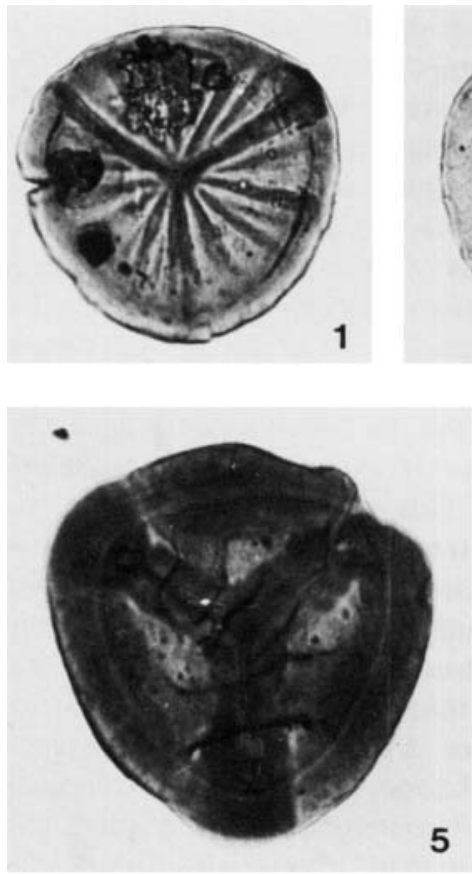

5

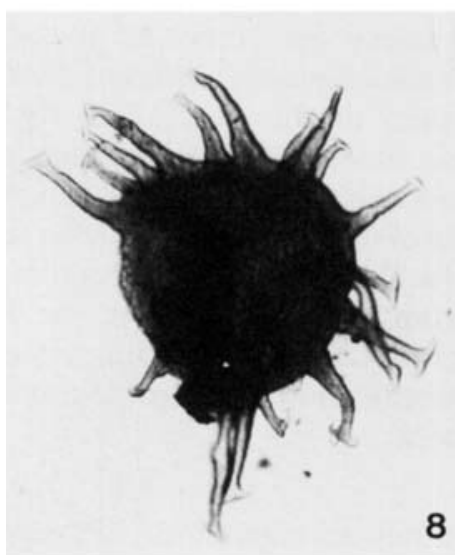

8

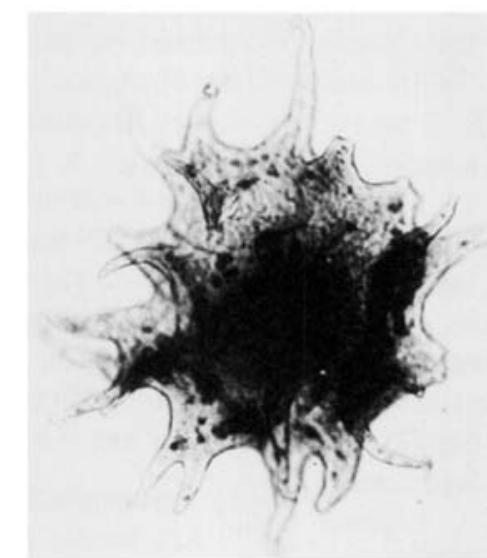

6
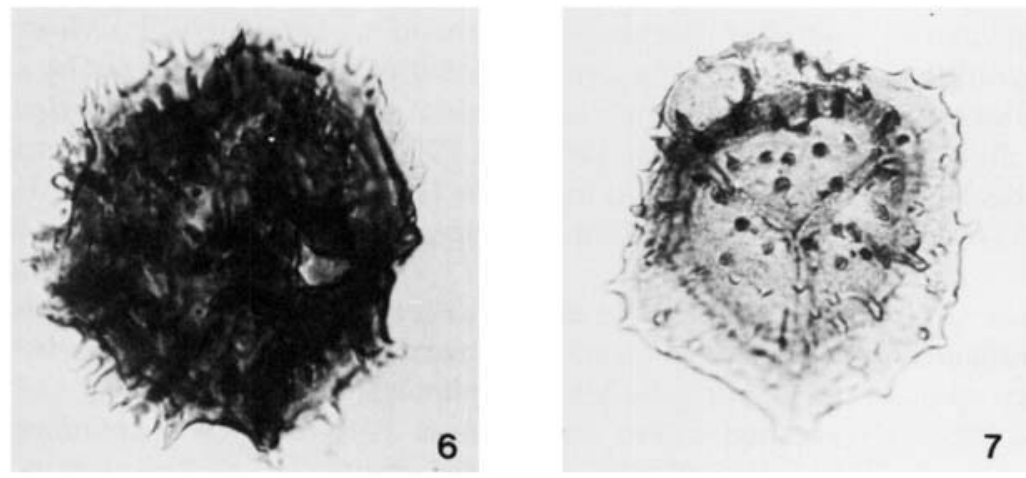

9
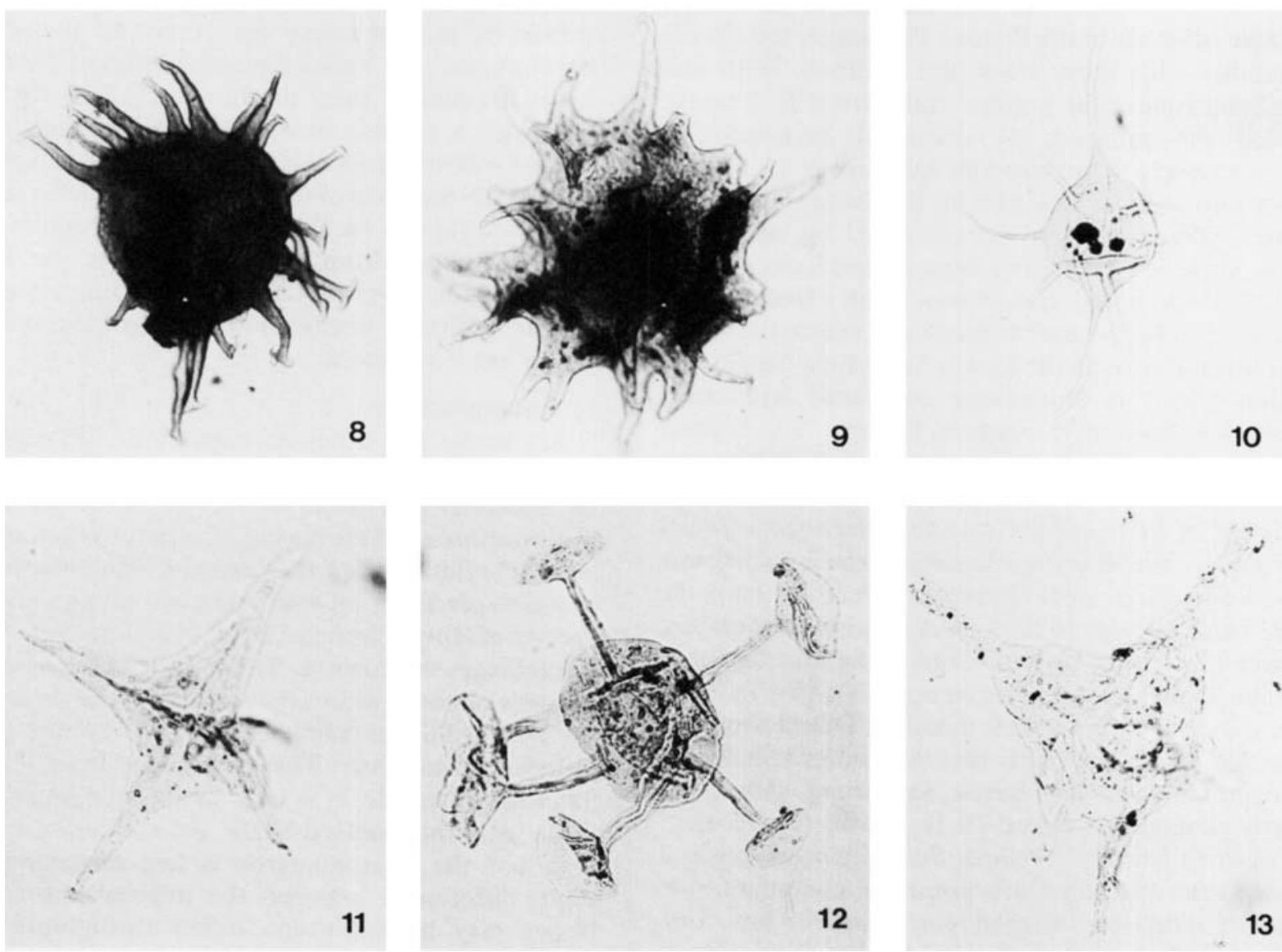
lepidophytus, Dictyotriletes [Reticulatisporites] fimbriatus, Lophozonotriletes cristifer and Vallatisporites pusillites were characteristic components of miospore assemblages from the Kettle Point Formation in the Courtright Borehole, southern Ontario. The succeeding Bedford Shale has a similar assemblage, and in addition contains Retusotriletes incohatus, Hystricosporites (Dicrospora) multifurcatus, Knoxisporites (Archaeozonotriletes) literatus, and ?Hymenozonotriletes explanatus. Spelaeotriletes lepidophytus, Dictyotriletes [Reticulatisporites] fimbriatus and Vallatisporites pusillites were recorded also from the Berea Sandstone in the nearby Gibraltar Borehole. Independent biostratigraphical evidence for the age of these formations is extremely sparse, being limited to conodont evidence from the Kettle Point Formation (Winder, 1966), where the presence of Spathognathodus inornatus (Branson \& Mehl) is taken to indicate an uppermost Upper Devonian age.

Close comparisons can also be drawn with miospore assemblages documented by Streel \& Traverse (1978) in their study of the Devonian - Mississippian transition in the classic Horseshoe Curve section near Altoona, Pennsylvania. The assemblages recovered from the Lower Sandstone Member and the Middle Sandstone and Shale Member of the Pocono Formation are closely comparable with those from the Bedford Shale and Berea Sandstone of the present study. Streel \& Traverse recorded the presence of abundant Spelaeotriletes lepidophytus and Cirratriradites hystricosus ( $=$ Vallatisporites pusillites) in the Middle Sandstone and Shale Member, where they are accompanied by infrequent representatives of Rugospora flexuosa and Knoxisporites literatus. They noted the presence of Cirratriradites hystricosus (=Vallatisporites pusillites) without Spelaeotriletes lepidophytus in the Lower Sandstone Member, a situation which is anomalous compared with their relative distributions in western Europe. The highest sample from the Middle Sandstone and Shale Member of the Pocono Formation yielded an assemblage dominated by Dictyotriletes sp. and Hymenozonotriletes explanatus, in which neither Spelaeotriletes lepidophytus nor Vallatisporites were present. Streel \& Traverse assigned an Fa $2 \mathrm{c}$ age to the Lower Sandstone Member, an upper Tn 1a-lower Tn $1 \mathrm{~b}$ age to the Middle Sandstone and Shale Member, and an upper Tn $1 b-\operatorname{Tn} 2$ age to the uppermost part of that member. Direct comparisons with central Ohio imply that the Bedford Shale and the lower part of the Berea Sandstone should be similarly assigned an upper Tn $1 \mathrm{a}-$ lower Tn $1 \mathrm{~b}$ age.

In western Europe, Spelaeotriletes lepidophytus and Vallatisporites pusillites are common components in sediments dated on independent conodont and foraminiferal evidence as Fa 2d - Tn 1a in the Dinant Basin of Belgium and northern France. In other areas (i.e. the Namur Basin and Sauerland), both species are known also to extend into the lower part of $\mathrm{Tn} 1 \mathrm{~b}$. Both species have been utilised as zonal indices with their simultaneous appearance defining the Vallatisporites pusillites - Spelaeotriletes lepidophytus (PL) Miospore Zone, the base of which is close to the base of Fa 2d. Other taxa from this zone in Belgium that were also recorded in the present Ohio samples include Rugospora flexuosa, Retusotriletes incohatus, Auroraspora hyalina and, in the uppermost part of the zone, isolated representatives of Hymenozonotriletes explanatus (see Clayton et al. 1977). In Belgium, the PL Zone is succeeded by the Dictyotriletes trivialis - Hymenozonotriletes explanatus (TE) Miospore Zone, in which assemblages are characterised by abundant Hymenozonotriletes explanatus and Dictyotriletes sp. This zone has, for facies reasons, a limited application and the alternative Verrucosisporites nitidus - Vallatisporites vallatus (NV) Miospore Zone erected in the South Munster Basin of southern Ireland is more widely used. Clayton et al (1974) have subdivided this zone into two subzones, the lower of which, the Spelaeotriletes lepidophytus - Verrucosisporites nitidus (LN) Subzone, has its base defined by the appearance of Verrucosisporites nitidus, which is present in the Bedford Shale and Berea Sandstone assemblages examined here. This subzone is also characterised by the continued occurrence of Spelaeotriletes lepidophytus and Vallatisporites pusillites (albeit with a lower frequency than in the preceeding PL Zone) Although a precise independent dating of the Irish sequence of miospore zones is not possible, it is probable that the LN Subzone of the NV Miospore Zone is of Late Devonian (lower Tn 1b) age. The close similarity with the assemblages from the upper part of the Bedford Shale and the lower part of the Berea Sandstone would appear sufficient justification for a comparable lower Tn $1 \mathrm{~b}$ age assignment.

\section{b) Microplankton}

Acritarchs and other microplankton (Prasinophyta) were obtained from each of the four samples. Specimens are generally well preserved, but are not as abundant as the miospores and the species diversity in each sample is low with relatively few taxa present. The microplankton assemblages from all four samples are dominated by species of Gorgonisphaeridium. The composition of the assemblages is shown in Table 2. There are no major changes in composition between the assemblages from the Bedford Shale (samples 2, 3 and 4) although slight differences do occur. The assemblage from the Berea Sandstone (sample 1) is very similar in composition to those from the Bedford Shale, but contains even fewer taxa and the microplankton is less abundant. These slight differences between the microplankton assemblages may be important, either stratigraphically or ecologically, but given the relatively sparse data available, it is not possible to comment on any significance at present. 
Table 2. Stratigraphic distribution of microplankton

MICROPLANKTON TAXA

Bedford Berea

\begin{tabular}{|c|c|c|c|c|}
\hline & & & & \\
\hline & 4 & 3 & 2 & 1 \\
\hline Cymatiosphaera spp. & $\mathbf{x}$ & $\mathbf{x}$ & $\mathbf{x}$ & $\mathbf{x}$ \\
\hline Duvernaysphaera radiata Brito & $\mathbf{x}$ & $\mathbf{x}$ & & $\mathbf{x}$ \\
\hline Exochoderma irregulare Wicander & $\mathbf{x}$ & $\mathbf{x}$ & $\mathbf{x}$ & $\mathbf{x}$ \\
\hline Florisphaeridium? sp. & $\mathbf{x}$ & $\mathbf{x}$ & & \\
\hline Gorgonisphaeridium ohioense (Winslow) Wicander & $\mathbf{x}$ & $\mathbf{x}$ & $\mathrm{x}$ & $\mathbf{x}$ \\
\hline G. winslowii Staplin, Jansonius \& Pocock & $\mathbf{x}$ & $\mathbf{x}$ & $\mathbf{x}$ & $\mathbf{x}$ \\
\hline G. spp. & $\mathbf{x}$ & $\mathbf{x}$ & $\mathrm{x}$ & $\mathrm{x}$ \\
\hline Leiosphaeridia spp. & $\mathbf{x}$ & $\mathbf{x}$ & $\mathbf{x}$ & $\mathbf{x}$ \\
\hline Maranhites mosesii (Sommer) Brito & & & $\mathbf{x}$ & \\
\hline Multiplicisphaeridium spp. & $\mathbf{x}$ & $\mathbf{x}$ & $\mathrm{x}$ & $\mathbf{x}$ \\
\hline Polyedrixium aff. embudum Cramer & & $\mathbf{x}$ & $\mathbf{x}$ & \\
\hline Pterospermella spp. & $\mathbf{x}$ & & $\mathbf{x}$ & $\mathbf{x}$ \\
\hline Puteoscortum polyankistrum Wicander \& Loeblich & & & & $\mathbf{x}$ \\
\hline Stellinium comptum Wicander \& Loeblich & $\mathbf{x}$ & $\mathbf{x}$ & & \\
\hline Stellinium micropolygonale (Stockmans \& Williere) Playford & $\mathbf{x}$ & & & \\
\hline Tasmanites spp. & $\mathbf{x}$ & $\mathrm{x}$ & $\mathbf{x}$ & $\mathbf{x}$ \\
\hline Umbellasphaeridium saharicum Jardine et al. & $\mathbf{x}$ & $\mathbf{x}$ & $\mathbf{x}$ & \\
\hline Unellium elongatum Wicander & $\mathbf{x}$ & & $\mathbf{x}$ & \\
\hline$U . \mathrm{sp}$. & $\mathbf{x}$ & & & \\
\hline Veryhachium roscidum Wicander & $\mathbf{x}$ & $\mathbf{x}$ & $\mathbf{x}$ & $\mathbf{x}$ \\
\hline Veryhachium sp. & $\mathbf{x}$ & $\mathbf{x}$ & $\mathbf{x}$ & $\mathbf{x}$ \\
\hline
\end{tabular}

Winslow's (1962) account of the Upper Devonian and Lower Mississippian palynology of Ohio is concerned mainly with miospores. Nevertheless, it does contain descriptions and illustrations of several acritarch species from the Bedford Shale and Berea Sandstone, including Unellium elongatum (as Hystrichosphaeridium cf. $H$. longispinosum) and Gorgonisphaeridium ohioense (as Hystrichosphaeridium ohioense), both of which have been recorded in the present study. More recently, Wicander $(1974,1975)$ has reported specifically on the microplankton from the Bedford Shale and the underlying Cleveland and Chagrin Shale Members of the Ohio Black Shale. In common with the present study, Wicander noted that levels of microplankton species diversity and abundance are low in the Bedford Shale. Wicander's material was obtained from the Barberton test core 3, drilled in Summit County, northeastern Ohio. Comparison of sample depths given by Wicander (1975) with stratigraphical data presented by Winslow (1962) indicates that Wicander's uppermost sample was collected immediately below the contact of the Bedford Shale with the Berea Sandstone, a position equivalent to that of sample 2 in this study. Wicander (1975) recorded only six taxa in his uppermost sample, five of which are also present in sample 2. These are Exochoderma irregulare, Gorgonisphaeridium ohioense, Leiosphaeridia spp., Tasmanites spp. and Veryhachium roscidum. The sixth of Wicander's species, Pterospermella capitana, has not been recorded in this study, but the genus Pterospermella is represented in both the Bedford Shale and Berea Sandstone. Another species present in sample 2, Unellium elongatum, was also described by Wicander from the Bedford Shale, but he recorded its latest occurrence within the top $10 \mathrm{ft}$. of the Bedford Shale, not immediately below the Berea Sandstone as in this account. The occurrence of all these taxa in samples 3 and/or 4 is however consistent with Wicander's record of their occurrence in the Bedford Shale.

The major difference between Wicander's study and the present account lies in the occurrence of species not previously recorded from the Bedford Shale or Berea Sandstone. However, four species do have North American records. Stellinium comptum, Stellinium micropolygonale (as Stellinium octoaster) and Puteoscortum polyankistrum have been recorded from the Antrim Shale of Frasnian/Famennian age in Indiana (Wicander \& Loeblich, 1977). Stellinium micropolygonale has been recorded from the Upper Devonian of 
Alberta (Staplin, 1961, as Veryhachium octoaster), from the Late Devonian Chagrin and Cleveland Shales underlying the Bedford Shale in Ohio (Wicander, 1974, 1975 as Stellinium octoaster), and from the Emsian, Eifelian and Givetian of the Moose River Basin, Ontario (Playford, 1977). The present record of these species in the Bedford Shale and Berea Sandstone is later than their previous North American records, and implies either reworking or an upward extension of their ranges. In the case of Stellinium micropolygonale, an upward extension of its range is quite possible since the species has been recorded from the latest Devonian elsewhere (e.g. Lanzoni \& Magloire, 1969; Playford, 1976 and see the discussion below). The fourth species with a previous North American record, Gorgonisphaeridium winslowii, was recorded from the Lower Mississippian Banff Formation of Alberta (Staplin et al., 1965). Species recorded herein that do not have prior North American records, include Duvernaysphaera radiata, Maranhites mosesii and Umbellasphaeridium saharicum.

Several species have well documented occurrences outside North America. Five species have been recorded by Lanzoni \& Magloire (1969) from the Upper Devonian and Lower Carboniferous of the Grand Erg Occidental in the Algerian Sahara. According to these authors, Duvernaysphaera radiata and Maranhites mosesii are present in the Upper Famennian, Strunian (i.e. preCarboniferous Tournaisian, Tn 1a and lower Tn 1b) and
Lower Tournaisian (i.e. Carboniferous), Gorgonisphaeridium ohioense (recorded as "Baltisphaeridium sp. No. 419-47") occurs in the Upper Famennian and Strunian, and Stellinium micropolygonale (=Veryhachium octoaster) and Umbellasphaeridium saharicum (recorded as "acritarche a entonnoirs' no. 441-33") are restricted to the Strunian. Subsequent work in the Algerian Sahara has extended the range of some of these species. Jardine et al. (1974) recorded Duvernaysphaera radiata between the Couvinian or Givetian and the Strunian, Stellinium micropolygonale (=Stellinium octoaster) between the Siegenian and the Strunian, Maranhites mosesii between the Frasnian and the Strunian and Umbellasphaeridium saharicum between the Frasnian or Famennian and the Strunian. Attar et al. (1980) confirmed that Maranhites mosesii is present in the Lower Tournaisian of the Basin d'Illizi, also in the Algerian Sahara, whereas Umbellasphaeridium saharicum does not occur above the Strunian. Attar et al. also illustrated a specimen of Gorgonisphaeridium winslowii from the Strunian.

Outside North Africa, Duvernaysphaera radiata, Maranhites mosesii and Umbellasphaeridium saharicum are present in the Middle and Upper Devonian of Brazil (Sommer, 1956; Brito, 1967a, 1967b). Stellinium micropolygonale has a widespread and long-ranging occurrence although it appears to be restricted to the Devonian (see Playford, 1976; Wicander \& Loeblich,

\section{Explanation of Plate 2}

Fig. 1. Cymatiosphaera sp. Specimen MPK 4020. Sample 4. England Finder co-ordinates H54/0 $(\times 780)$.

Fig. 2. Stellinium micropolygonale (Stockmans \& Williere, 1960) Playford, 1977. Specimen MPK 4021. Sample 4. England Finder co-ordinates T60/3 $(\times 1200)$.

Fig. 3. Pterospermella sp. Specimen MPK 4022. Sample 1. England Finder co-ordinates 042/1 $(\times 490)$.

Fig. 4. Puteoscortum polyankistrum Wicander \& Loeblich, 1977. Specimen MPK 4023. Sample 1. England Finder co-ordinates $\mathrm{J} 37 / 2(\times 780)$.

Fig. 5. Duvernaysphaera radiata Brito, 1976b. Sample 1. Specimen MPK 4024. England Finder co-ordinates E46/0 $(\times 780)$.

Fig. 6. Maranhites mosesii (Sommer, 1956) Brito, 1967a. Specimen MPK 4025. Sample 2. England Finder coordinates $042 / 0(\times 490)$.

Fig. 7. Puteoscortum polyankistrum Wicander \& Loeblich, 1977. Specimen MPK 4026. Sample 1. England Finder co-ordinates S59/3 $(\times 780)$.

Fig. 8. Gorgonisphaeridium winslowii Staplin, Jansonius \& Pocock, 1965. Specimen MPK 4027. Sample 2. England Finder co-ordinates $042 / 4(\times 780)$.

Figs. 9, 12. Polyedrixium aff. embudum Cramer, 1964. Specimen MPK 4028. Sample 2. England Finder co-ordinates $\mathrm{U} 51 / 3(\times 490)$.

Fig. 10. Tasmanites sp. Specimen MPK 4029. Sample 2. England Finder co-ordinates 066/0 ( $\times 490)$.

Fig. 11. Gorgonisphaeridium ohioense (Winslow, 1962) Wicander, 1974. Specimen MPK 4030. Sample 2. England Finder co-ordinates M43/3 ( $\times 780)$. 

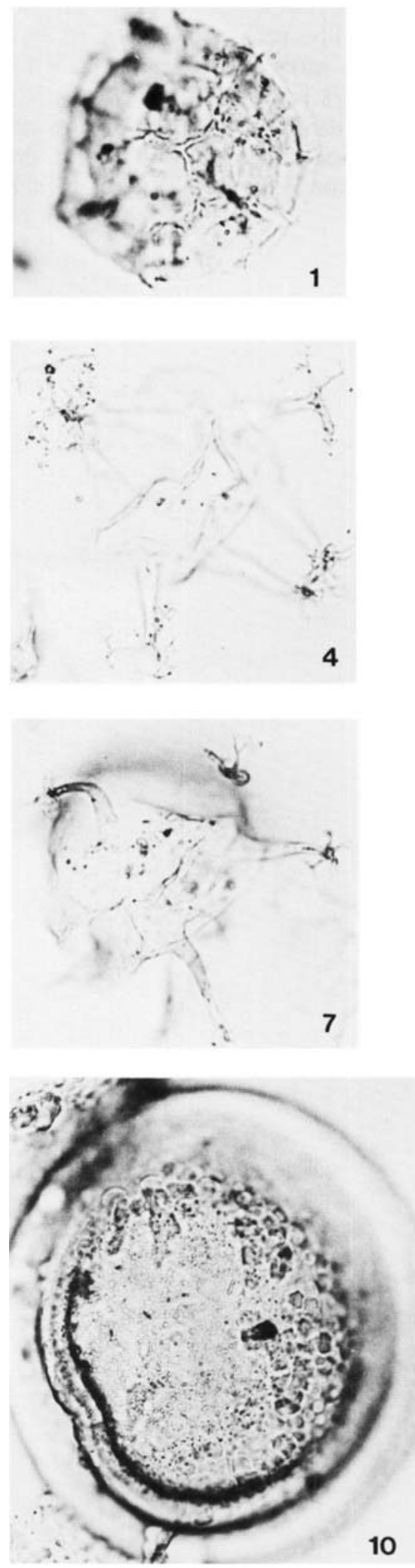

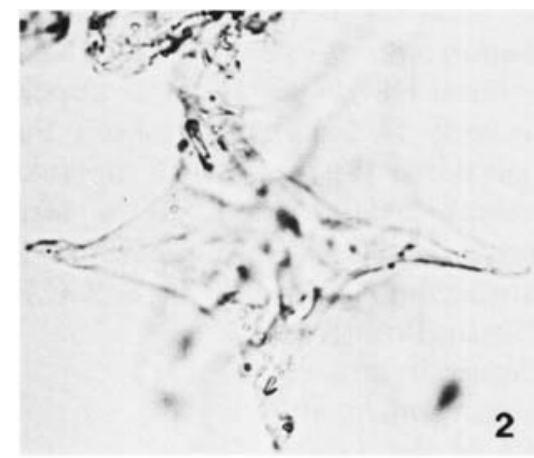

3

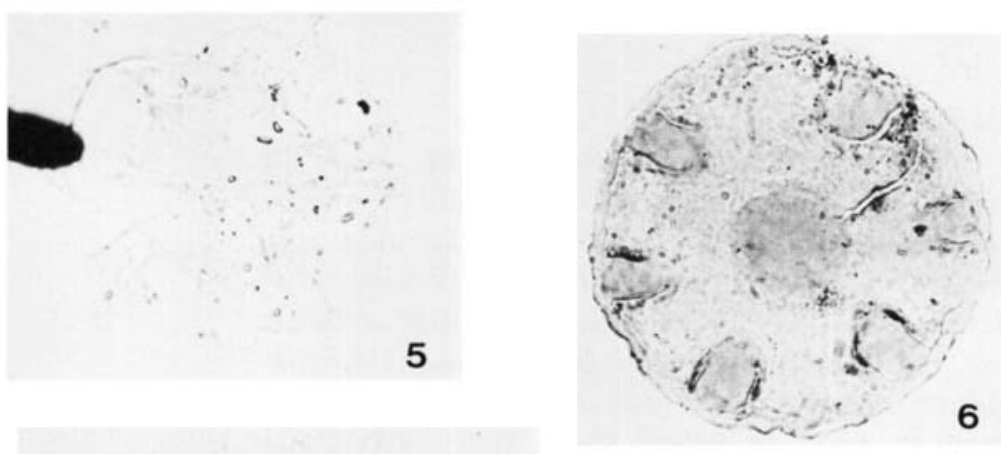

8

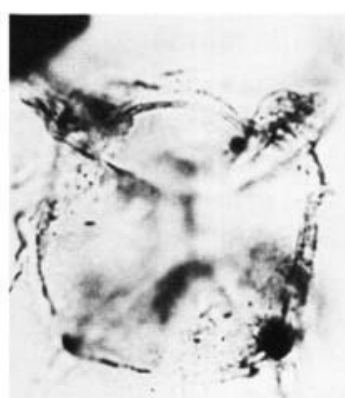

9

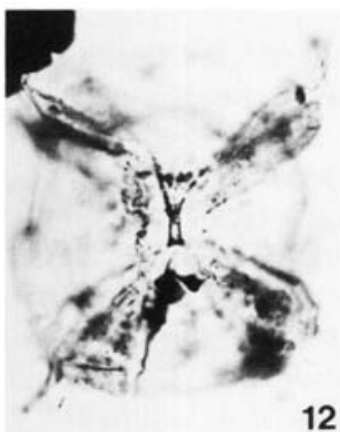


1977; Martin, 1981 for summaries of the geographical and stratigraphical distribution of this species). In Western Australia, Playford (1976) has recorded Gorgonisphaeridium ohioense and Stellinium micropolygonale (= Stellinium octoaster) from the latest Devonian (Famennian Fa 2d to Strunian Tn 1a or early Tn 1b) of the Canning Basin. In Belgium, Vanguestaine (1978) has recorded Gorgonisphaeridium ohioense, Stellinium micropolygonale (=Stellinium octoaster) and Veryhachium roscidum from the Upper Famennian (Fa 2c, $\mathrm{Fa} 2 \mathrm{~d}$ ) and the Strunian ( $\operatorname{Tn} 1 \mathrm{a}$ ) in the Dinant Basin, and Martin (1981) has recorded Exochoderma irregulare, Stellinium comptum, Stellinium micropolygonale and Unellium elongatum in the upper part of the Lower Famennian on the southern margin of the Dinant Basin.

\section{CONCLUSIONS}

The miospores recorded in this account from the Bedford Shale and Berea Sandstone provide the principal evidence for a Late Devonian (pre-Carboniferous Tournaisian) age and most of the microplankton recorded are consistent with this. Gorgonisphaeridium ohioense, Stellinium micropolygonale and Umbellasphaeridium saharicum do not occur above the Late Devonian in sections which cross the Devonian Carboniferous boundary in North Africa (Lanzoni \& Magloire, 1969; Attar et al., 1980) and in Western Australia (Playford, 1976). The ranges of other species present, as documented above, coincide in part with the latest Devonian. Stellinium comptum and Puteoscortum polyankistrum are the exceptions, and have not been recorded previously above the Famennian.

The ages proposed herein and by Eames (1978) for the Bedford Shale and Berea Sandstone in central and northeastern Ohio mean that the published ranges of several species need to be revised. These are the species for which a Mississippian occurrence is based solely on Wicander's $(1974,1975)$ record of their presence in the Bedford Shale which he regarded as being of Mississippian age following Winslow's (1962) account. They include Exochoderma irregulare, Gorgonisphaeridium ohioense, Veryhachium roscidum and Unellium elongatum. There is, so far, no evidence that any of these or the other species described by Wicander range upwards into the Carboniferous.

Wicander \& Loeblich (1977) have commented on the apparent rarity of cosmopolitan microplankton species in the Late Devonian, pointing out that only five species occurring in the Late Devonian of North America had been recorded elsewhere in the world. However, Vanguestaine (1978) and Martin (1981) have recorded a number of North American species in the Late Devonian of Belgium, and the present work documents the occurrence in North America of species previously recorded from North Africa, South America and
Australia. There are still considerable differences between worldwide Late Devonian microplankton assemblages. A number of species described from North America have yet to be recorded elsewhere, but some taxa appear to be more widespread than hitherto realised. Further work is needed to clarify the extent of microplankton provincialism in the late Devonian.

Drs. Molyneux and Owens publish with the permission of the Director of the British Geological Survey (N.E.R.C.). 


\section{REFERENCES}

Attar, A., Fournier, J., Candilier, A. M. \& Coquel, R., 1980. Etude palynologique du Dévonian terminal, et du Carbonifère inférieur du bassin d'Illizi (Fort-Polignac) Algérie. Rev. Inst. Fr. Pet., 35, 585-618.

Brito, I. M. 1967 a. Novo subgrupo de acritarcha do Devoniano do Maranhão. An. Acad. Brasil Ci., 39, 163-6.

Brito, I. M. 1967b. Silurian and Devonian acritarcha from Maranhao Basin, Brazil. Micropaleontology, 13, 473-82.

Clayton, G., Higgs, K. J., Gueinn, K. J. \& Van Gelder, A. 1974. Palynological correlations in the Cork Beds (Upper Devonian - ?Upper Carboniferous) of southern Ireland. Proc. R. Ir. Acad., Sec. B. 74, 145-155.

Clayton, G., Coquel, R., Doubinger, J., Gueinn, K. J., Loboziak, S., Owens, B. \& Streel, M. 1977. Carboniferous Miospores of Western Europe: illustration and zonation. Meded. Rijks Geol. Dienst., 29, 1-71.

Conil, R., Groessens, E. \& Pirlet, H. 1977. Nouvelle charte stratigraphique du Dinantien type de la Belgique.Ann. Soc. Geol. Nord., 96 (4), 363-371.

Cramer, F. H. 1964. Microplankton from three Paleozoic formations in the province of León, N.W. Spain. Leidse Geol. Meded., 30, 253-361.

De Witt W., Jr. 1970. Age of the Bedford Shale, Berea Sandstone and Sunbury Shale in the Appalachian and Michigan Basins, Pennsylvania, Ohio and Michigan. U.S. Geol. Surv. Bull., 1294-G, G1-G11.

Eames, L. E. 1978. A palynologic interpretation of the Devonian - Mississippian boundary from northeastern Ohio, U.S.A. (abst.) Palynology, 2, 218-219.

Haas, W. H. 1947. Conodont zones in the Upper Devonian and Lower Mississippian formations of Ohio. J. Paleont., 21, 131-141.

Hoover, K. V. 1960. Devonian - Mississippian Shale sequence in Ohio. Ohio Geol. Surv., Inf. Circ., 27, 1-154.

Jardine, S., Combaz, A., Magloire, L., Peniguel, G. \& Vachey, G. 1972. Acritarches du Silurien terminal et du Dévonien du Sahara algérien. C.R. 7e Congr. Int. Carb. Stratigr. Geol. (Krefeld 1971), 1, 295-311.

Jardine, S., Combaz, A., Magloire, L., Peniguel, G. \& Vachey, G. 1974. Distribution stratigraphique des acritarches dans le Paléozoique du Sahara algérien. Rev. Palaeobotan. Palynol., 18, 99-129.

Lanzoni, E. \& Magloire, L. 1969. Associations palynologiques et leurs applications stratigraphiques dans le Dévonien supérieur et Carbonifère inférieur du Grand Erg Occidental (Sahara algérien). Rev. Inst. Fr. Pet., 24; 441-68.

Martin, F. 1981. Acritarches du Famennien inférieur a Villerssur-Lesse (Belgique). Bull. Inst. r. Sci. nat. Belg., 51, 1-49.
McGregor, D. C. 1967. Composition and range of some Devonian spore assemblages in Canada. Rev. Palaeobotan. Palynol., 1, 173-183.

McGregor, D. C. 1970. Hymenozonotriletes lepidophytus Kedo and associated spores from the Devonian of Canada. in Colloque sur la Stratigraphie du Carbonifère. Congrès et Colloques Univ. Liège, 55, 315-326.

McGregor, D. C. 1979. Devonian miospores of North America. Palynology, 3, 31-52.

Pepper, J. F., De Witt, W. Jr., \& Demaret, D. F. 1954. Geology of the Bedford Shale and Berea Sandstone in the Appalachian Basin. U.S. Geol. Surv. Prof. Pap., 259, 1-111.

Playford, G. 1976. Plant microfossils from the Upper Devonian and Lower Carboniferous of the Canning Basin, Western Australia. Palaeontographica, Abt. B., 158, 1-71.

Playford, G. 1977. Lower to Middle Devonian acritarchs of the Moose River Basin, Ontario. Bull. geol. Surv. Can., 279, 87 pp.

Sommer, F. W. 1956. Novas espécies de Tasmanites do Devoniano do Para. An. Acad. Brasil Ci., 28, 455-63.

Staplin, F. 1961. Reef controlled distribution of Devonian microplankton in Alberta. Palaeontology, 4, 392-424.

Staplin, F., Jansonius, J. \& Pocock, S. A. J. 1965. Evaluation of some acritarchous hystrichosphere genera. N. Jb. Geol. Paläont. Abh., 123, 167-201.

Stockmans, F. \& Williere, Y. 1960. Hystrichosphères du Dévonien belge (Sondage de l'Asile d'aliénés a Tournai). Senckenberg. leth., 41, 1-11.

Streel, M. \& Traverse, A. 1978. Spores from the Devonian/ Mississippian transition near the Horseshoe Curve section, Altoona, Pennsylvania, U.S.A.Rev. Palaeobotan. Palynol., 26, 21-39.

Vanguestaine, M. 1978. Acritarches du Famennien superieur du sondage de Tohogne (Belgique) et correlation biostratigraphique transcontinentale. Palinologia, num. extraord. 1, 481-487.

Wicander, E. R. 1974. Upper Devonian-Lower Mississippian acritarchs and prasinophycean algae from Ohio, U.S.A. Palaeontographica Abt. B, 148, 9-43.

Wicander, E. R. 1975. Fluctuations in a late Devonian-early Mississippian phytoplankton flora of Ohio, U.S.A. Palaeogeogr. Palaeoclimatol. Palaeoecol., 17, 89-108.

Wicander, E. R. \& Loeblich, A. R. 1977. Organic-walled microphytoplankton and its stratigraphic significance from the Upper Devonian Antrim Shale, Indiana, U.S.A. Palaeontographica Abt. B, 160, 129-65.

Winder, C. G. 1966. Conodont zones and stratigraphic variability in Upper Devonian rocks, Ontario. J. Paleontol., 40, 1275-1293.

Winslow, M. R. 1962. Plant spores and other microfossils from the Upper Devonian and Lower Mississippian rocks of Ohio. U.S. Geol. Surv. Prof. Pap., 364, 1-93. 